al-Ihkam: Jurnal Hukum dan Pranata Sosial, 14 (2), 2019: 221-235

ISSN: 1907-591X, E-ISSN: 2442-3084

DOI: http://doi.org/10.19105/al-ihkam.v14i2.2631

\title{
Marriage Settlement among Minority Muslim by Datok Imam Masjid in South Thailand
}

\author{
Umi Supraptiningsih \\ Faculty of Syariah Institut Agama Islam Negeri Madura, \\ Jl. Raya Panglegur, Km. 04 Tlanakan Pamekasan 69371 \\ Email: umistainpamekasan@gmail.com \\ Khoirul Bariyyah \\ Abroad Alumni Association of Southern Border Province \\ Nongcik Road, No. 122/68, M.4.T Rooseemeelae, Mueang, \\ Pattani-94000, Thailand
}

Article history: Received: 29 September 2019,

Accepted: 12 November 2019, Published: 15 December 2019

\begin{abstract}
:
Most of Thailand Moslem community live at the plateau of its South area. As the minority, they cannot perform sharia laws formally under official acknowledgment. Therefore, in practicing the law, particularly marriage settlement, they rely on the rules of figh school followed by each local Datok Imam Masjid. The Datok exists in every village even sub-village and is a delegation from the Committee of Islam at Province. However, The Committee does not arrange particular rules in the marriage settlement so that the practice is fully guided and handled by the Datok. This research uses qualitative approach through descriptive method. It finds that principles and requirements of marriage settlement are in line with common Islamic laws in the Qur'an and hadith. Most of South Thailand Datok serving as penghulu (staffs of marriage settlement) furthermore affiliate to Shafi'i school. However, as each datok has different views and beliefs on certain issues, the rules
\end{abstract}


become too flexible such as the minimum age for the brides and bridegrooms or the existence of wali (Islamic guardian mainly from the family line) as the marriage requirement. Additionally, the marriage settlement with a newly converted Muslim and "free" polygamy are two big issues as there found no exact rule governing all the details. The settlement is also sometimes often hard to hold due to expensive request of mahr (dowry) which causes the high number of eloping cases.

\title{
Keywords:
}

Islamic Law; Marriage Settlement; South Thailand Moslem, Datok

\begin{abstract}
Abstrak:
Sebagian besar Muslim Thailand hidup di daerah Selatan dataran tinggi. Sebagai minoritas, mereka tidak dapat mempraktikkan aturan syariah secara resmi yang diakui negara, termasuk dalam pernikahan. Oleh karenanya, pernikahan dilaksanakan berdasarkan peraturan mazhab fiqh yang diikuti masing-masing Datok Imam Masjid. Datok ini terdapat di setiap desa, bahkan kampung, dan merupakan utusan Komite Islam Provinsi yang berwenang mengurus berbagai urusan keagamaan. Karena Komite Islam Thailand sendiri juga tidak menetapkan aturan pasti tentang pernikahan, Datok-lah yang dalam praktiknya mengarahkan dan menangani urusan ini. Penelitian ini menggunakan pendekatan kualitatif dan metode deskriptif. Hasilnya menunjukkan bahwa prinsip dan rukun pernikahan ala Datok sudah sesuai dengan hukum Islam di Al-Qur'an dan hadist. Selain itu, sebagian besar Datok yang menjadi juru nikah diketahui bermazhab Syafi'i. Meski demikian, perbedaan pengetahuan dan sikap masing-masing Datok terhadap isu-isu tertentu menyebabkan longgarnya aturan dalam pernikahan, seperti usia minimal kedua calon mempelai dan keberadaan wali sebagai syarat pernikahan. Termasuk juga di antaranya adalah pernikahan dengan muallaf serta maraknya pernikahan poligami tanpa adanya batasan khusus. Selain itu, pelaksanaan
\end{abstract}


pernikahan seringkali terhambat oleh permintaan jumlah mahar yang tinggi sehingga menyebabkan banyaknya kasus kawin lari.

\section{Kata Kunci:}

Hukum Islam; Pernikahan; Muslim Thailand Selatan, Datok

\section{Introduction}

Marriage is a commitment to establish a legal relationship between a man and a woman for living together in a family, continuing offspring, preventing adultery, and keeping the peaceful condition of a society. ${ }^{1}$ In this context, marriage settlement causes a legal relationship between a man and a woman as well as their relation with community, state, and also God. Religions urge marriage as it aims to create a prosperous world and in Islam, the rules of marriage settlement are well mentioned at the Qur' an and hadith.

Marriage is one of the sunnah practices of Prophet Muhammad pbuh for all Moslems around the world, including those as minority. Because the marriage aims to prevent adultery, its settlement requires certain principles and requirements. This becomes important because any lack of its principles and requirements will cause the marriage invalid.

Islam has been widespread all over the world since a few centuries ago. In general, Muslim communities in various countries can be categorized as follow; First, Muslim communities in Islamic states such as in Saudi Arabia, Iran, and Pakistan. Second, Muslim communities in non-Islamic states but being the majority of their population, such as in Egypt, Turkey, and Indonesia. Third, Muslim communities in non-Islamic states and being the minority, such as in Thailand, Philippines, and some European and African countries. ${ }^{2}$

The term minority refers to the community with different characteristics from the common society or the majority in a certain

\footnotetext{
1 Abd. Shomad, Hukum Islam: Penormaan Prinsip Syariah dalam Hukum Indonesia (Jakarta: Kencana, 2010), 274.

2 Cik Hasan Basri, Peradilan Agama (Jakarta: Raja Grafindo Persada, 1998), 19.
} 
area or country. ${ }^{3}$ The differences range from language, culture, ethnicity, religion, to other basic diversity which distinguish one and another. Thailand, in this context, is one of non-Islamic states with Buddhists as the majority. Moslems become one of the minority groups with about $4 \%$ of its total population. ${ }^{4}$

Islam came to Thailand through Pattani and was brought by Arab traders who came to Malay for business. Initially, Islam was a dominant religion among Pattani's society (Al-Fathoni, now becoming a part of South Thailand) as also indicated by the change of kingdom style. It was the Nobels and the King who played a vital role in replacing the Hindu-Buddha style with an Islamic one. However, in 1902, Pattani Kingdom was successfully conquered by the government of Thailand and consequently, the kingdom becomes a South Thailand until nowadays. It has three provinces namely Yala, Narathiwat, and Pattani. ${ }^{5}$ From that moment on, Islam has been increasingly widespread in several regions of Thailand. ${ }^{6}$

South Thailand consists of 14 provinces, namely Chumphon, Krabi, Nakhon Si Thammarat, Phang Nga, Phattalung, Phuket, Ranong, Satung, Songkhla, Surat Thani, Trang, Pattani, Yala, and Narathiwat. Most of South Thailand Muslims live in certain provinces of its area such as Pattani, Yala, Narathiwat, and Satun. Relating to this, The Royal Decree of 1902 on local government administration stated that "all of the laws and the rules must be based on the King agreement". 7

The enactment of Islamic family and inheritance law in Thailand is still limited in most of aspects because the government only acknowledges the application at its four provinces with Muslim

${ }^{3}$ Yusuf Qardhawi, Figh Minoriti, ed. Muhammad Hanif Hasan (Kuala Lumpur: SH. Noordeen, 2002), 5.

4 M. Ali Kettani, Minoritas Muslim di Dunia Dewasa Ini, ed. Zarkowi Soejoeti (Jakarta: PT. Raja Grafindo Persada, 2005), 200.

5 Bahriyatul Arif, "Pelaksanaan Syariah Islam Di Thailand," Harian Jawa Pos, June 2015.

${ }^{6}$ Nathan Porath, "Muslim Schools (Pondok) in the South of Thailand: Balancing Piety on a Tightrope of National Civility, Prejudice and Violence," South East Asia Research 22, no. 3 (September 1, 2014): 303-19, https://doi.org/10.5367/sear.2014.0217.

${ }^{7}$ Arif, "Pelaksanaan Syariah Islam di Thailand." 
majority population as stated in the Rule of The Application of Islamic Law our Provinces 1946. It mentions that "Islamic family Law and inheritance shall be applied in the first-court in Pattani, Narathiwat, Yala, and Satun." ${ }^{8}$ It was due to the choice of local people not to recognize themselves as the Thai Muslims and preferred as Malay Muslims instead. Therefore, the Thailand government provided them an autonomic right in religious affairs. This led them to think about formulating Islamic family Law and inheritance acts of Thailand. ${ }^{9}$

As a consequence, the Law and act are not valid for Muslims in other parts of Thailand. They usually do not have any specific rules for a marriage settlement because the Thailand government doesn't recognize any shariah law. In dealing with the marriage settlement, they rely on a specific figh school (mazhab). Meanwhile, to get legal acknowledgment, they must follow the state regulation.

The marriage settlements among Moslem communities in those several provinces of South Thailand are performed by each local Datok Imam Masjid. They were elected through voting ${ }^{10}$ among members of each mosque and have the authority to hold marriage settlement among Muslim minority in Thailand while guiding the process. Meanwhile, The Islamic Center Committee acknowledged by the King of Thailand is the one that deals with administrative matters and marriage certificate issuance. The committee is under the management of Sheikh al-Islam or mostly known as Chularajmontri in the Thai language. His main duty is giving advice or direction for the

8 Ramizah wan Muhammad, "The Dato Yuthitham and The Administration of Islamic Law in Southern Thailand. Islam, Syari'ah and Governance Background Paper Series" (Melbourne-Australia, 2011), 6.

${ }^{9}$ Waeburaheng Waehayee, "Konsep Wali Nikah Dalam Undang-Undang Hukum Keluarga Islam Thailand" (UIN Sunan Kalijaga Yogyakarta, 2008).

${ }^{10}$ Songsiri Putongchai, "What Is It like to Be Muslim in Thailand?: A Case Study of Thailand through Muslim Professionals Perspectives" (Exeter University Saudi Arabia, 2013), 176, It was stated in The Islamic Organization Administrative Act of 1997 that "members of each mosque choose their mosque committee. 
King in carrying out administration relating to marriage registration, zakat payment, and mosque affairs. ${ }^{11}$

Interestingly, each local Datok Imam Masjid has different views on marriage settlement practice. The same goes on for the preferred figh school. This diverse view greatly influences the quality of marriage settlement practice in Thailand as a logical consequence of the election system. There is no specific qualification needed to be a Datok such as a broad perspective on marriage settlement, religious competency and other skills or knowledge related to the marriage settlement.

However, the majority of Thai Moslems are Sunni with Syafi'i school even though other schools like Hanafi and Syiah still exist. At least, this is clear from the existence of various literature and Islamic Law books in Thailand's local educational institutions. ${ }^{12}$

So far, the four Imām Madzhab as the main references of ijtihād practice among worldwide scholars is those who lived in the golden age of Islam and not in any country with a Muslim minority. Thus, the compiled figh books mostly provide a solution in an ideal social condition where Muslim become the majority, live in a safe condition and are led by a pious Sultan with absolute Islamic sovereignty. ${ }^{13}$

In fact, many problems arise among Muslim as the minority ranging from law, economy, ethic, household conflict to marriage settlement because of limitation in many aspects to formally perform Islamic law. Furthermore, in the context of Thailand, the surrounding condition makes it hard to perform Islamic law because, among others, forbidden things in Islam culturally exist in Thailand such as interfaith marriage and same-sex marriage. Therefore, as a minority group, they must have Islamic life guidelines based on the shariah system appropriate with each condition and universally acceptable. ${ }^{14}$

${ }^{11}$ Muhammad, "The Dato Yuthitham and The Administration of Islamic Law in Southern Thailand. Islam, Syari'ah and Governance Background Paper Series."

12 Waehayee, "Konsep Wali Nikah Dalam Undang-Undang Hukum Keluarga Islam Thailand."

${ }^{13}$ Ahmad Sarwat, Fiqih Minoritas (DU CENTER PRESS, 2010), 1.

${ }^{14}$ Ahmad Sarwat, Fiqih Minoritas. 
From this context, it is necessary to conduct a study on marriage settlement among the Muslim minority of South Thailand who can not legally perform it according to Islamic law. This paper aims to know the practice of marriage settlement among the Muslim minorities in South Thailand and analyze its Islamic law perspective.

\section{Method}

This research uses a qualitative approach through the descriptive-analytical method. In this case, the researcher became the key instrument or the data compiler using interviews and documentation. Therefore, the researcher's attendance has an important role to get valid data and information in line with the research purpose. As this is pure research, the researcher's identity is known by the subject. ${ }^{15}$

The researcher conducted this study for four months in South Thailand while doing Student Exchange. This made it possible for the researcher to get valid data from informants directly. Meanwhile, the research location was at the plateau of South Thailand, namely Chumpon, Ranong, Surat Thani, Pang-nga, Phuket, Krabi, Nakhon Si Thammarat, Trang and Pattalung. The area was selected as it is the home of most of Thailand Muslim and the absence of formal codified shariah law found in the area.

Mostly, the primary data is obtained directly from the community while the secondary is from the literature review. ${ }^{16}$ The former came from the Thailand Islamic scholars serving as penghulu (staffs of marriage settlement) and other local public figures like Islamic teachers and local people. ${ }^{17}$ Meanwhile, the secondary data was from documentation relating to marriage such as marriage law or figh munäkahah ooks. Afterward, the data analysis is by using nonstatistic analysis which consists of checking and organizing.

\section{Marriage Settlement in Minority Figh among Muslim}

\footnotetext{
${ }^{15}$ Kamarudin, Pengantar Metodologi Riset (Bandung: Angkasa, 1972). 78

${ }^{16}$ Soerjono Soekanto, Pengantar Penelitian Hukum (Jakarta: UI Press, 1986), 51.

17 Duncan McCargo, "Autonomy for Southern Thailand: Thinking the Unthinkable?," Pacific Affairs 83, no. 2 (June 18, 2010): 261-81, https://doi.org/10.5509/2010832261.
} 
Minority refers to a community with different characteristics from the majority. The differences vary from religion, language, to other basic diversities which distinguish one and another. Meanwhile, Muslim refers to Islam adherents. Thus, Muslim minority is a group of Muslim whose number is less than non-Moslem communities in a country or area. ${ }^{18}$

The apostasy or conversion cases of Muslim rarely occur in any Moslem minority country. However, when a Moslem community adopts non-Islamic cultures which later inttttfluence their Islamic identity, interfaith marriages number significantly increases. It has nothing to do with the increasing number of newly converted Muslim because it becomes the primary evidence of the social and cultural assimilation process instead. ${ }^{19}$

Religious difference between the future couple is the primary issue among the Moslem minority which possibly leads to difficulties to settle a marriage. A marriage between Moslem male and nonMoslem female (musyrik in the Qur'anic term or idolatrous) is prohibited in the Qur'an. The term refers to an idol worshiper like Quraisy infidels who believed in non-Abrahamic religion and Majus people who worshipped the fire. Their female community members are forbidden to be married to. However, this is not valid for Ahl Kitāb women (Jewish and Christians) because most of the prophet companions married them. Nevertheless, some scholars disagree with this because they categorize the Jewish and Christian as idolatrous communities who worship Jesus even three Gods at once.

\section{Marriage Settlement among Moslem Minority in South Thailand}

The Thai Muslim community is more diverse than the Malay Muslim community in Thailand. Even though realizing the ethnic diversity while still maintaining their religious tradition, most Thai Muslim speak in Thai and have assimilated with the Thai Buddhist community. Additionally, Muslims in each province of Thailand have experienced the same social interaction through education, media, market, and any public institution. Furthermore, they have also practiced Thai norms and culture besides their religious practices.

\footnotetext{
${ }^{18}$ Qardhawi, Figh Minoriti.

${ }^{19}$ Kettani, Minoritas Muslim Di Dunia Dewasa Ini.
} 
The Thai Muslim community interacts with the government through religious bureaucracy led by Chularajmontri office, Central Islamic Committee, and Representative of Provincial Islamic Committee under the management of the Department of Home affairs. Their staff is elected through voting and serve to arrange and manage mosques as well as any local educational activities. Mosques and Islamic schools (boarding schools) have become the key institutions of social interaction among the Muslim community. They also become centres for activities on fasting month, Eid al-Fitr and Eid al-Adha prayers, jumu'ah prayer, corpse burial process, Qur'an recitation, marriage settlement, and other religious activities. A mosque committee also serves to manage waqf and deserves legal acknowledgment as well as subsidy from the government through Islamic bureaucracy and the Department of home affairs. ${ }^{20}$

The practice of marriage settlement in South Thailand is mainly based on Syafi'i school as what generally occurs in Indonesia. ${ }^{21}$ However, it is handled by Datok Imam Masjid from the bride's home area as the staff of marriage settlement. Therefore, a Muslim should register themselves first to the Datok by submitting an ID Card. Then, he will ask the background of the brides, the bridegrooms, and their families to fulfill the marriage principles. The Datok will issue the 'unofficial' marriage certificate legalized by The Provincial Islamic Committee. Next on, the couple must register their marriage for the second time to the Registry Office for getting legal acknowledgment from the Thailand government. ${ }^{22}$

The registration of marriage through Datok is far easier. The couple only needs to submit their ID cards and there are no rules on the minimum age of both bride and bridegroom as the standard is baligh (religiously mature). However, the Registry Office in Thailand requires them to fulfill various requirements for the marriage registration such as the minimum age at 17 years old, birth certificate

${ }^{20}$ Malik Ibrahim, Seputar Gerakan Islam Di Thailand: Suatu Upaya Melihat Faktor Internal Dan Eksternal (Yogyakarta: Sosio Religia, 2012), 147-48.

${ }^{21}$ Zulkeflee, "The Head of the Religious Field at School and Khoteb in Trang," (2015), Direct interview, (26 July 2015).

${ }^{22}$ Husna Kepan, "The Wife of Khoteb Masjid of Muang Trang," (2015), Direct interview, (16 August 2015). 
and family card. Additionally, a marriage certificate of the Provincial Islamic Committee is also available for second, third or fourth wives. On the contrary, a formal marriage certificate is only available for the first wife as the government neither acknowledges nor allows polygamy. The legal marriage certificate enables wives and children to get some facilities, such as allowance for a worker husband, social assurance, free health and education service for the state school as well as the requirement for job application. ${ }^{23}$

After submitting the ID card, the Datok will ask the rest of the marriage principles and requirements. The principles are in line with the common Islamic laws as stated in the Qur'an and hadith, which are the existence of the future next bride and bridegroom, wali (guardian) for the bride, two marriage witnesses, and the statement of ijāb qabūl. Meanwhile, the requirements are also similar to those in Indonesia, except for the minimum age for both. One of them is about the Muslim status for both. Thus, if one of them is non-Muslim, he/she must willingly convert to Islam first before the marriage settlement takes place. ${ }^{24}$

As for the guardian (wali), it mainly comes from the family line due to the priority arrangement in Syafi'i school. However, a woman has a right to choose a magistrate guardian in certain cases such as unwillingness, unreachable distance or the absence of family guardians. ${ }^{25}$ Meanwhile, the marriage witness can be chosen by the staff of marriage settlement or from relatives of the couple. The requirements consist of; 1) psychologically healthy, 2) bāligh or religiously mature, 3) Muslim, 4) two men 5) having good eyesight and hearing. ${ }^{26}$

23 Jar Radeng, “Ustadzah Patthalung," (2015), direct interview, September 2015).

.${ }^{24}$ Suwanee Makman, "The Child of Datok Imam Masjid of Muang Krabi," (2015), direct interview, (24 September 2015). See Nantawan Haemindra, "The Problem of the Thai-Muslims in the Four Southern Provinces of Thailand (Part Two)," Journal of Southeast Asian Studies 8, no. 1 (March 7, 1977): 85-105, https://doi.org/10.1017/S0022463400015666

${ }^{25}$ Zulkeflee, "The Head of the Religious Field at School and Khoteb in Trang."

${ }^{26}$ Zulkeflee. 
Another main part is the $i j a \bar{a} b$ qabūl process which must be done by the bridegroom with the guardian at the same time and place with clear and comprehensible pronunciation. ${ }^{27}$ It usually takes place either in the bride's house or the mosque. The latter is typically chosen for unapproved marriage, polygamy, or a simple wedding ceremony. ${ }^{28}$

One thing mentioned in ijāb qabūl is the dowry. The bridegroom needs to give it to the bride before ijab qabul takes place. Besides, it needs to calculate the dowry very carefully to avoid any error in mentioning it at the ijāb qabūl process as the dowry is the absolute right of a married woman. ${ }^{29}$ Generally, it is the bride or her family who determines the number or type of dowry, although a few cases show that it depends on the bridegroom consideration and decision. ${ }^{30}$

In general, Muslim marriage settlement in South Thailand looks similar to the practice in other areas. The difference lies in the marriage requirement as the more detailed explanation as follow:

First, there is no minimum age for the brides and the bridegrooms because the valid standard is bāligh. Islam suggests any mature and responsible person to get married. In any Muslim minority country, early marriage is even recommended to prevent any negative things such as promiscuity and moral decadence.

Second, women can choose a magistrate guardian (wali hakim) easily without considering the existence of wali nasab (family lineage guardian). This makes it easy to hold a marriage settlement as they wish to do.

Third, there is no specific requirement for two marriage witnesses as the consequence of a very minimum number of Muslim men around. Therefore, the witness can be either a just or a wicked person. Fourth, there found two-time marriage administration at Representative of Provincial Islamic Committee through Datok Imam Masjid and Registry Office. The former is for religious legality while the latter is for state acknowledgment to assure the right of Thai citizens.

\footnotetext{
${ }^{27}$ Zulkeflee.

${ }^{28}$ Makman, "The Child of Datok Imam Masjid of Muang Krabi."

${ }^{29}$ Kepan, "The Wife of Khoteb Masjid of Muang Trang."

${ }^{30}$ Makman, "The Child of Datok Imam Masjid of Muang Krabi."
} 
Apart from those differences, it is interesting to find that many unregistered marriages exist in South Thailand because the local people consider marriage certificates unimportant. Additionally, South Thailand marriage settlements are relatively simple yet much money-consuming for dowry and souvenirs given to the brides.

In the case of polygamy, the Thai government neither acknowledges nor allows the practice and consequently, it is only the first wife who gets the legal right and access. However, many Muslims build polygamy families in the absence of related specific rules. Moreover, some of them believe that Muslim in any minority country should choose polygamu for syar'i reason, such as the higher number of women than those of men, preventing interfaith marriage, avoiding moral decadency and others.

Based on this perspective, a Muslim husband is required to either ask permission from his first wife or let her know about polygamy whether or not he gets the approval. Polygamy is considered legal as long as the woman (as the next wife) certainly knows that the man she will get married to is a married one. Most of the wives in South Thailand are workers or breadwinners and this makes it easier for any husbands who will do polygamy.

On the contrary to polygamy, the Thailand government allows interfaith marriage. Therefore, a Muslim who will get married to a non- Muslim, either Buddhist or others, needs to hold the marriage settlement in the City Hall because Datok does not allow interfaith marriage for Moslem although at the same time, he can't avoid anyone from doing it. ${ }^{31}$ However, it is only a few Muslim who does interfaith marriage in addition to the fact that the number of interfaith marriage cases in South Thailand is less than the number of those in North Thailand. ${ }^{32}$

The blurred stand of Datok concerning interfaith marriage leads to the conversion to Islam because it is forbidden for Muslims to get married to the apostates (murtad). Unfortunately, a marriage settlement with a newly converted Moslem is not followed or preceded by any specific Islamic training to create a true Moslem.

${ }^{31}$ Zulkeflee, "The Head of the Religious Field at School and Khoteb in Trang."

32 Radeng, “Ustadzah Patthalung." 
Thus, any newly convert finds it hard to adapt to Islam and this potentially leads to back conversion. In this condition, Datok or another religious leader can not separate the married couple even though one of them has been already apostate.

\section{Conclusion}

Most of the marriage settlement practices in South Thailand follow Syafi'i school and are handled by Datok Imam Masjid as the local staff of religious affairs under the Provincial Islamic Committee which issue "unofficial" marriage certificate. Therefore, the marriage settlement must be registered again to Registry Office for getting an official marriage certificate. The principle and requirement of marriage settlement according to the Datok generally agree to common Islamic laws, such as the absence of minimum age for the future couple, prohibition for an interfaith marriage unless a conversion takes place beforehand, and the existence of guardian as well as witnesses. However, at other specific issues of marriage, such as polygamy and interfaith marriage, and the number of dowry, each Datok has different perspective and decision. Furthermore, certain issues such as interfaith marriage is legally allowed in Thailand while at the practice, most newly converted Muslems who get married to Muslims can not adapt to Islamic teaching then it leds them to a back conversion.

\section{Bibliography}

Ahmad Sarwat. Fiqih Minoritas. DU CENTER PRESS, 2010.

Abdurrahim, Syaikh Ahmad. 2015. Tuhfatu al-'Arusyain, terj. Umar Mujtahid, Solo: Aqwam.Arif, Bahriyatul.

“Pelaksanaan Syariah Islam Di Thailand.” Harian Jawa Pos, June 2015.

Basri, Cik Hasan. Peradilan Agama. Jakarta: Raja Grafindo Persada, 1998.

Dewi, Puspita, Meizara, Eva, dan Basti, Konflik Perkawinan dan Model Penyelesaian Konflik Pada Pasangan Suami Istri, Jurnal Psikologi, 
Vol. 2, No. 1, Desember 2008.

Haemindra, Nantawan. "The Problem of the Thai-Muslims in the Four Southern Provinces of Thailand (Part Two)." Journal of Southeast Asian Studies 8, no. 1 (March 7, 1977): 85-105. https:// doi.org/10.1017/S0022463400015666.

Ibrahim, Malik. Seputar Gerakan Islam Di Thailand: Suatu Upaya Melihat Faktor Internal Dan Eksternal. Yogyakarta: Sosio Religia, 2012.

Kamarudin. Pengantar Metodologi Riset. Bandung: Angkasa, 1972.

Kepan, Husna. “The Wife of Khoteb Masjid of Muang Trang.” 2015.

Kettani, M. Ali. Minoritas Muslim Di Dunia Dewasa Ini. Edited by Zarkowi Soejoeti. Jakarta: PT. Raja Grafindo Persada, 2005.

Lestari, Rika, Perbandingan Penyelesaian Sengketa Perceraian Secara Mediasi di Pengadilan dan di Luar Pengadilan di Kabupaten Kampar. Jurnal Hukum IUS QUIA IUSTUM, No. 2, Vol. 21, April 2014.

Makman, Suwanee. "The Child of Datok Imam Masjid of Muang Krabi." 2015.

McCargo, Duncan. "Autonomy for Southern Thailand: Thinking the Unthinkable?" Pacific Affairs 83, no. 2 (June 18, 2010): 261-81. https://doi.org/10.5509/2010832261.

Muhammad, Ramizah wan. "The Dato Yuthitham and The Administration of Islamic Law in Southern Thailand. Islam, Syari'ah and Governance Background Paper Series." MelbourneAustralia, 2011.

Porath, Nathan. "Muslim Schools (Pondok) in the South of Thailand: Balancing Piety on a Tightrope of National Civility, Prejudice and Violence." South East Asia Research 22, no. 3 (September 1, 2014): 303-19. https:// doi.org/10.5367/sear.2014.0217.

Putongchai, Songsiri. "What Is It like to Be Muslim in Thailand?: A Case Study of Thailand through Muslim Professionals Perspectives." Exeter University Saudi Arabia, 2013.

Qardhawi, Yusuf. Figh Minoriti. Edited by Muhammad Hanif Hasan. Kuala Lumpur: SH. Noordeen, 2002.

Rahayu, Sri Lestari, Mulyanto, dan Mayastuti, Anti, Penguatan Fungsi Kepala Desa Sebagai Mediator Perselisihan Masyarakat Desa, Yustisia, Vol. 5, No. 2, Mei-Agustus 2016.

Radeng, Jar. “Ustadzah Patthalung.” 2015. 
Shomad, Abd. Hukum Islam: Penormaan Prinsip Syariah Dalam Hukum Indonesia. Jakarta: Kencana, 2010.

Soerjono Soekanto. Pengantar Penelitian Hukum. Jakarta: UI Press, 1986.

Waehayee, Waeburaheng. “Konsep Wali Nikah Dalam UndangUndang Hukum Keluarga Islam Thailand." UIN Sunan Kalijaga Yogyakarta, 2008.

Zulkeflee. "The Head of the Religious Field at School and Khoteb in Trang." 2015. 